\title{
Exploring spatial dependence of cowpea-beans yield using global and local autocorrelation statistics in the Eastern Cariri region of Paraíba
}

\author{
Antônia Silânia de Andrade ${ }^{1}$ (D) Madson Tavares Silva ${ }^{2 *}$ (D) Edivaldo Afonso de Oliveira Serrão ${ }^{1}$ (D) \\ Vicente de Paulo Rodrigues da Silva ${ }^{2}$ (D) Enilson Palmeira Cavalcanti ${ }^{2}$ \\ Enio Pereira de Souza ${ }^{2}$ (D) Célia Campos Braga ${ }^{2}$ (D)
}

${ }^{1}$ Programa de Pós-graduação em Meteorologia, Universidade Federal de Campina Grande (UFCG), Campina Grande, PB, Brasil.

${ }^{2}$ Unidade Acadêmica de Ciências Atmosféricas, Universidade Federal de Campina Grande (UFCG), 58109-970, Campina Grande, PB, Brasil. E-mail: madson.tavares@ufcg.edu.br. *Corresponding author.

ABSTRACT: This study evaluated the variability and characterizedthe spatial dependence between some soil attributes in the Eastern Cariri microregion of Paraiba, and analyzed the spatial correlations in order to identify the interactions between such attributes in cowpea bean(Vigna unguiculata L. Walp)production. Harvest data of the agricultural years of 2000-2017 in the Eastern Cariri microregion of Paraiba were analyzed. Parameters of the fitted models wereestimated using the Maximum Likelihood method and the performance of the models was evaluated based on coefficients of determination $\left(R^{2}\right)$, maximum log-likelihood function, and Schwarz's Bayesian information criterion (BIC). Correlation and spatial autocorrelation between the cowpea productivity and agrometeorological elements was detected through the spatial analysis, using techniques such as the Moran's index I. The study showed that, according to the performance indicators used, the spatial error model offered better results in relation to the classical multiple regression models and the self-regressive spatial models, indicating that the inclusion of spatial dependence in the models improves the estimate of productivity of cowpea in the microregion of Cariri Oriental da Paraiba. Key words: Variability, Productivity, Cowpea-beans, Spatial analysis.

Explorando a dependência espacial da produtividade do feijão-caupi usando estatísticas globais e locais de autocorrelação na região do Cariri oriental da Paraíba

RESUMO: $O$ estudo tem por finalidade avaliar a variabilidade e caracterizar a dependência espacial entre alguns atributos dos solos na microrregião do Cariri Oriental da Paraíba, bem como estudar as correlações espaciais para identificar as interações entre tais atributos na produção do feijão-caupi. O estudo foi realizado com os dados das safras dos anos agrícolas de 2000-2017, da microrregião do Cariri Oriental da Paraiba. A estimativa de parâmetros dos modelos ajustados foi obtida utilizando o método de Máxima Verossimilhança e a avaliação do desempenho dos modelos foi realizada com base no coeficiente de determinação $\left(R^{2}\right)$, no máximo valor do logaritmo da função verossimilhança e no critério de informação bayesiano de Schwarz (BIC). Este estudo também permitiu verificar a correlação e autocorrelação espacial entre a produtividade do feijão e dos elementos agrometeorológicos, por meio da análise espacial, usando de técnicas como o índice I de Moran. O estudo mostrou que, de acordo com os indicadores de desempenho utilizados, o modelo de erro espacial ofereceu melhores resultados em relação aos modelos clássicos de regressão múltipla e aos modelos espaciais autorregressivos, indicando que a inclusão da dependência espacial nos modelos melhora a estimativa da produtividade do feijão-caupi em a microrregião do Cariri Oriental da Paraíba. Palavras-chave: Variabilidade, Produtividade, Feijão-caupi, Análise espacial.

\section{INTRODUCTION}

The semiarid region of northeastern Brazil is characterized by high daytime and low nighttime temperatures, high solar radiation, low air humidity and low rainfall volume with intermittent, infrequent, random rainsconcentrated in a few months. Most soils are shallow, with low water-holding capacity, acidic $\mathrm{pH}$, and poor drainage. In some sites they are salinized and have low levels of some nutrients essential to plant growth and development. All of these characteristics limitagricultural and livestock production; and consequently, reflect on the regional economy and quality of life of the population (ALVES et al., 2017).

Swidden agriculture based on rainfed crops and slash-and-burn land clearing is the traditional model adopted in the semiarid region. In this system, farmers rely on their ability to interpret natural signs in order toplantheir agricultural calendar 
and decide when to start land preparation, planting and harvesting activities (NASUTI et al., 2013).

According to INSA (2014), most family farmers in the semiarid region do not have irrigation systems installed on their small properties, what implies that they are more vulnerable in the face of climate change. Climatic risks affect agriculture, resulting in major changes in crop productivity and efficiency of production methods (VERMEULEN et al., 2010; LITER \& BURSZTYN, 2015). Risks arising from climatic variability, such as those related to soil quality, water supply and distribution, availability of nutrients, and temperature, have a major influence on the potential productivity of many crops (BEDDINGTON et al., 2012).

SILVA et al. (2012) evaluated the impacts of climate change on the agricultural zoning of climate riskof sugarcane crops in the Northeast of Brazil, combining geoprocessing techniques with a water balance model to identify areas in which the crop could suffer yield restrictions due to climate change. SILVA et al. (2011a) carried out a similar study with cowpea crops grown in northeastern Brazil andidentified regional areas where they would have reduced yields due to climate change.

The present study evaluated the variability ofsome soil attributes, characterize their spatial dependence in the Eastern Cariri microregion of Paraíba, and analyze thespatial correlations so as to identify the interactions between these attributes in cowpea productivity.

\section{MATERIALS AND METHODS}

\section{Study area}

The study area is located in the Eastern Cariri microregion of the state of Paraíba (Figure 1), consisting of 12 municipalities. According to IBGE (2015) census data, the microregion has an area of $4,219,150 \mathrm{~km}^{2}$, with an estimated population of 63,704 inhabitants (IBGE, 2010).

The region is characterized by high temperatures (annual average around $26^{\circ}$ ), low thermal amplitudes (NASCIMENTO \& ALVES,

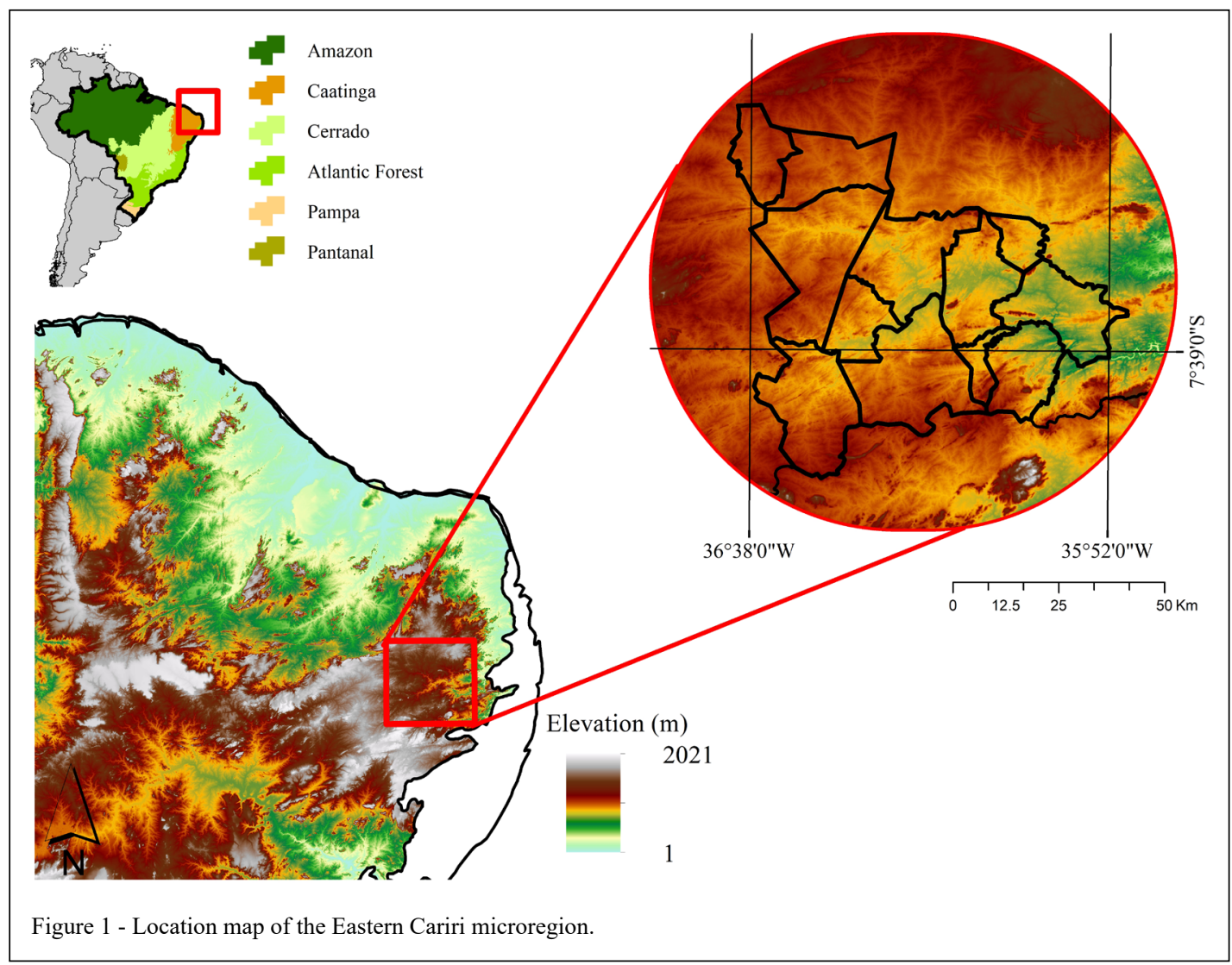

Ciência Rural, v.51, n.12, 2021. 
2008), and scarce rainfall with great variability in time and space, with annual average rainfall of 587 $\mathrm{mm}$ with a standard deviation of $\pm 230 \mathrm{~mm}$ (SENA et al., 2012).

Climatic data were collected from meteorological stations installed in the study area monitored by the National Meteorological Institute (INMET). For these locations, time series data from 2000-2017 were used in the analyses. Data from the IBGE Automatic Recovery System (SIDRA) for cowpea (Vigna unguiculata L. Walp) cultivation were used in the analysis of productivity.

The method proposed by THORNTHWAITE (1948) was adopted for climatic classification, where the humidity index was calculated using the Equation 1.The water index (Ih) reflects all the conditions prevailing during the year, covering dry and rainy periods, thus the water index (Ih) is the ratio between excess water and potential evapotranspiration expressed as a percentage (CUNHA \& MARTINS, 2009) (Eqution 1).

$I h=\frac{E X C}{E T P} \times 100$

where:EXC (Excess of Water): reflects the climatic subtype and differentiates the periods of excess and aridity that occurred during the year due to the intra-annual distribution of rainfall; ETP (Potential Evapotranspiration): it serves to indicate the direct function of temperature and photoperiod, being of fundamental importance for establishing the seasons of growth and development of cultures.

As for the drought-induced fallow index (Irs), it indicates the presence and intensity of drought outside the vegetative period and is obtained in a similar way to the vegetation drought index (Isv), considering only the points (months) that fall in the sub-humid, dry or arid sectors, except those already included in Irs.

\section{Moran's Index (I)}

Moran's index (I) is a statistical mechanism for verifying the spatial dependence of a given variable, being one of the most used for this purpose and estimated by the following expression, according to ALMEIDA et al. (2008) (Equation 2):

$I=\frac{\sum_{i=1}^{n} \sum_{j=1}^{n} w_{i j}\left(x_{i}-\mu\right)\left(x_{j}-\mu\right)}{\sum_{i=1}^{n}\left(x_{i}-\mu\right)^{2}}$

where: $n$ is the number of observations; $w_{i j}$ is the element in the neighborhood matrix for pair $i$ and $j$; $\mathrm{W}$ is the sum of the weights of the matrix; $x_{\mathrm{i}}$ and $x_{j}$ are deviations from the mean; $\mu$ is the mean.
This index measures the spatial autocorrelation based on the product of deviations from the mean. This index is a global measure of spatial autocorrelation as it indicates the degree of spatial association present in a given data set. The index values vary from -1 to 1 . The value is zero (0) indicates absence spatial dependence; positive values (between 0 and +1 ) indicate the existence of direct correlation, that is, perfect association with spatial dependence; and negative values (between 0 and -1 ) indicate an inverse correlation, that is, perfect dispersion.

\section{Spatial regression models}

Classical regression (CR)

A regression model (Equation 3) is based on the interest in evaluating the relationship of a given variable (Y) in relation to independent or covariate variables $(\mathrm{X})$, that is, the relationship between two or more variables so that one of them can be explained or predicted by others (CORRAR et al., 2007). In the case of spatial data, when there is spatial autocorrelation, the generated model must incorporate the spatial structure because the interdependent observations affect the predictive power of the model (CÂMARA $\&$ MONTEIRO, 2004).

$Y_{i}=\beta_{0}+\beta_{1} X_{1}+\beta_{2} X_{2}+\ldots+\beta_{n} X_{n}+\varepsilon_{i}$

where: $Y_{i}$ is the value of a given observation of the dependent variable; $X_{1}, X_{2}, \ldots, X n$ are the independent variables; $\beta=\left(\beta_{0}, \beta_{1}, \beta_{2}, \ldots, \beta_{\mathrm{n}}\right)$ are called the corresponding regression coefficients, and $\varepsilon_{i}$ is the error associated with the observations of the dependent variable.

The assumption that the observations are independent simplifies the model, but in the context of data referring to a given area, this simplification is unlikely because of the possibility of spatial dependence between the error terms. An alternative is to use mixed spatial autoregressive models (spatial lag models), in which the ignored spatial autocorrelation is attributed to the response variable $y_{i}$. Another alternative is the application of a spatial error model in which spatial effects are considered as noise, that is, as a factor to be removed (LESAGE \& FISCHER, 2010).

\section{Spatial autoregressive model (SAM)}

The spatial autoregressive model allows the observations of the dependent variable $y_{i}$ in area $i$ $(i=1, . ., n)$ to depend on observations in neighboring areas with $j \neq i$ (CÂMARA et al., 2004), taking the form (Equation 4):

Ciência Rural, v.51, n.12, 2021. 
$Y_{i}=\rho \sum_{j=1}^{n} W_{i j} y_{i}+\sum_{q=1}^{Q} X_{i q} \beta_{q}+\varepsilon_{i}$

where: $\varepsilon_{i}$ is the error, $W_{i j}$ is the $(i, j)$ element of the spatial matrix of order $n(n \times n)$. The scalar $\rho$ is a parameter (to be estimated) that will determine the intensity of the spatial autoregressive relationship between $y_{i}$ and $\sum j$ Wijyj; this parameter is interpreted as the average effect of the dependent variable in relation to the spatial neighborhood in the region analyzed. The $W y$ vector is known as the spatial lag, the $X$ matrix has the observations of the independent variables, and the $\beta$ vector has the coefficients for the independent variables.

\section{Spatial error model (SEM)}

In the spatial error model, spatial dependence is obtained through the error process, in which the errors of the different areas may present spatial covariance (BIVAND \& PIRAS, 2015), determined by the expression (Equation 5):

$\varepsilon_{i}=\rho \sum_{j=1}^{n} W_{i j} \varepsilon_{j}+u_{i}$

where: $\rho$ is the autoregressive parameter that indicates the intensity of spatial autocorrelation between the residuals of the observed equation and measures the average effect of the errors ofneighbors in relation to the residue of the region analyzed, and $u$ is the random error term, typically assumed to be i.i.d. Spatial autocorrelation in SEMs appears in the error terms.

(Equation 6):

In matrix notation, it can be written

$\varepsilon=\lambda \boldsymbol{W} \varepsilon+\boldsymbol{u}$

Assuming $|\lambda|<1$, the following expression is obtained (Equation 7):

$\varepsilon=(\boldsymbol{I}-\lambda \boldsymbol{W})^{-1} \boldsymbol{u}$

Inserting the above expression in the classical regression model, the following SEM is obtained (Equation 8):

$\boldsymbol{y}=\boldsymbol{X} \boldsymbol{\beta}+(\boldsymbol{I}-\lambda \boldsymbol{W})^{-1} \boldsymbol{u}$

With $E\left[u u^{\prime}\right]=\sigma^{2} I$, and the variance and covariance matrix defined as follows (Equation 9):

$E\left[\varepsilon \varepsilon^{\prime}\right]=\sigma^{2}(\boldsymbol{I}-\lambda \boldsymbol{W})^{-1}\left(\boldsymbol{I}-\lambda \boldsymbol{W}^{\prime}\right)^{-1}$

The SEM is characterized as a combination between a classical regression model and a SAM in terms of $\varepsilon$ error. Therefore, the value expected is the same as that of a classical regression model.

\section{Model selection}

According to DOBSON \& BARNETT (2011), the adjustment algorithm must be applied not only to one model, but to several from a very wide set that must be relevant to the nature of the observations to be analyzed. If the process is applied to a single model without taking into account possible alternative models, there is a risk of missing models that provide better fit to the data. Similar to usual regression models, according to the Akaike criterion, a sub-model for which the quantity below is minimal must be found (Equation 10):

$A I C=D(y ; \hat{\mu})+2 p$

where: $D(y ; \hat{\mu})$ is the distance between the logarithm of the likelihood function of the saturated model $(q$ parameters) and of the model under investigation ( $p$ parameters) evaluated in the maximum likelihood estimate $\hat{\beta}$. A small deviation value indicates that the fit of the model with fewer parameters is as good as that of the saturated model.

The possibility of using the Bayesian methodology to identify models was mentioned by Akaike, and some statisticians present it as the Bayesian Information Criterion. The minimum BIC estimated for a given model is used to select optimal models in various fields of statistics. TheBIC calculation for a defined model is estimated using (Equation 11):

$B I C=-2 \log L_{i}+p_{i} \log n$

where: $\mathrm{L}=$ Max likelihood: the parameter with the highest probability of correctly representing the relationship between the input and output; $p=$ the number of parameters; $n=$ the number of values in the data set.

In the interpretation of the correlation coefficients generated by the statistical models, the values were classified according to ROWNTREE \& O’HEHIR (1981) and are presented in table 1.

Table 1 - Correlation intensity classification.

\begin{tabular}{ll}
\hline Classification & Interval \\
\hline Very weak & $0.0-0.2$ \\
\hline Weak & $0.2-0.4$ \\
\hline Moderate & $0.4-0.7$ \\
Strong & $0.7-0.9$ \\
\hline Very strong & $0.9-1.0$ \\
\hline
\end{tabular}

Source: ROWNTREE \&O'HEHIR (1981); adapted: Author (2020).

Ciência Rural, v.51, n.12, 2021. 


\section{RESULTS AND DISCUSSION}

The agriculture developed in the studied area is of the subsistence type and irregular due to the inconsistency of the rainy season in the semiarid region. Most of the production is exploited under rainfed conditions, and bean and corn are the most economically important crops. Any crop grown under rainfedconditions inevitably depends on the quantity, distribution and intensity of rainfall,and on the interactions between phenological phases and interannual weather and climate variation (SILVA et al., 2002). These crops are generally grown in consortium or with forage such as buffel grass and/or forage palm, reaching good yield rates especially in years with normal rainy season.

SILVA et al. (2010) pointed out that an increase in air temperature affected the availability of adequate agricultural areas, in particularforcowpea beanin northeastern Brazil, and recommended that cowpea varieties better adapted to high temperatures should be adopted in the region. The impacts of climate change are highly variable in space and time due to the variability of air temperature, precipitation, soil and vegetation across the region. The landscape of rural areas in the Northeast of Brazil is characterized by crops that are well adapted to semiarid climatic conditions such as cowpea (SILVA et al., 2010). Figure 2 shows the municipalities that stand out in the production of cowpea bean. The most productive are Boqueirão and São João do Cariri, with an average annual production of 114 and 57.55 tons, respectively. Other municipalities, such as Alcantil, Santo André, Caturité, Barra de São Miguel and Gurjão, also have good accumulated production, while Riacho de Santo Antônio has low production when compared to other cities.

Based onknowledge about the accumulated bean crop production in municipalities of the Eastern Cariri microregion, the Moran's index Iwas used to estimate the level of spatial autocorrelation between the municipalities that are part of the Eastern Cariri microregion of Paraíba.

In figure 3 , it is possible to observe a conglomerate that presents a negative spatial autocorrelation, indicating that the neighboring relations are of the Low-High and High-Low type. In the High-Low typology, the municipalities presented high bean production while neighboring municipalities had low values for the same variable,

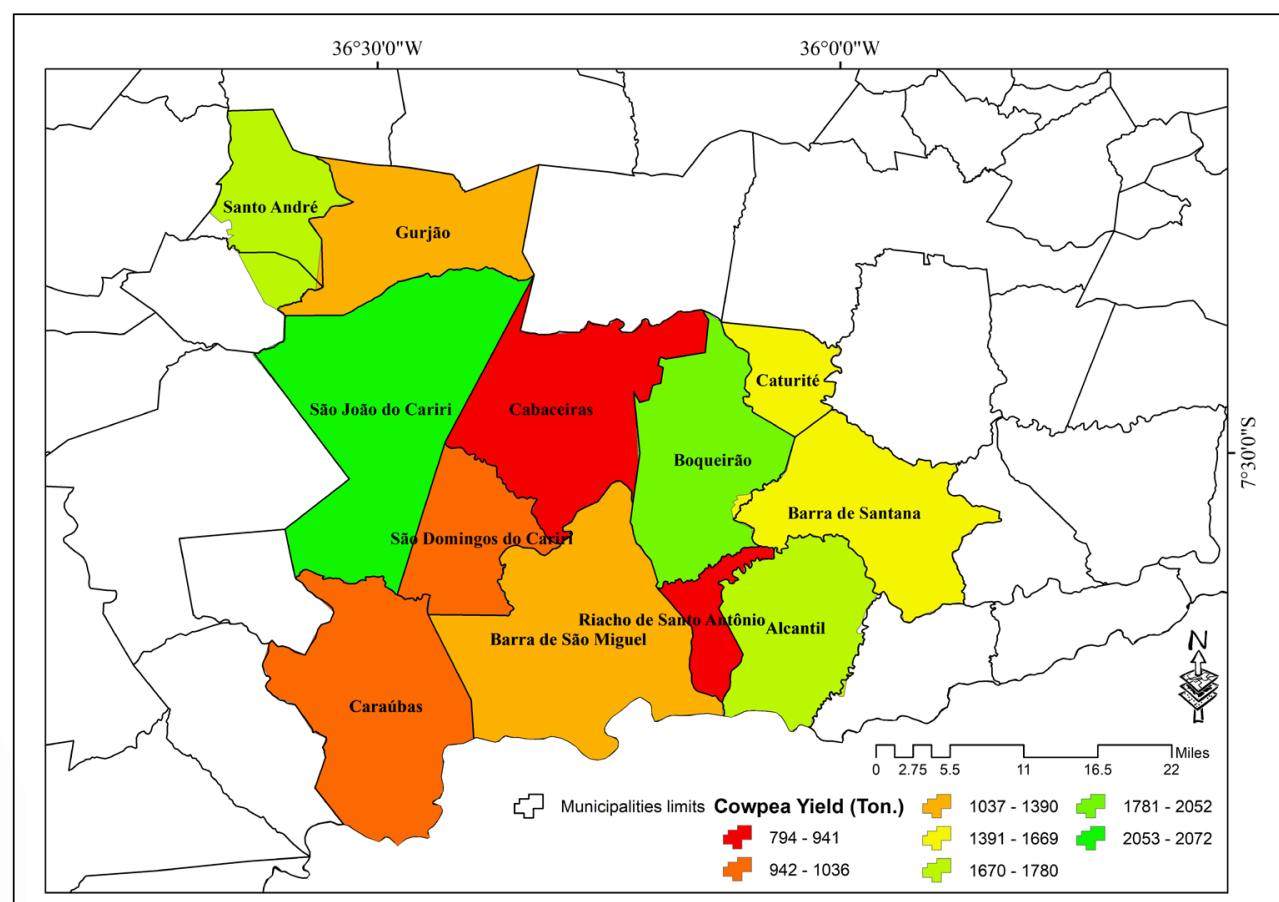

Figure 2 - Accumulated production of cowpea in the period 2000-2017 in the Eastern Cariri microregion of Paraíba. 


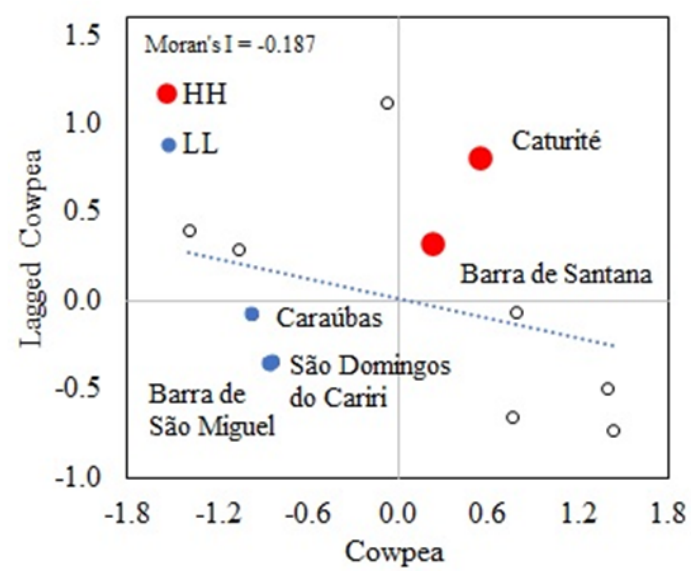

Figure 3 - Moran's scatter plot for cowpea production in the Eastern Cariri microregion of the state of Paraíba.

and in the Low-High typology, the municipalities presented low values while neighboring municipalities had high values.

From this degree of autocorrelation, it can be inferred that, in the municipalities of the HighHigh (HH) typology (1st quadrant), the cultivation of the grain legume had great relevance among all agricultural activities. In other words, cowpea cropsare relevant in these municipalities compared to other types of agriculture and livestock production.

The presence of dots in the second and fourth quadrant (Q2 and Q4) indicates the dispersion of data in space and the absence of similar data clusters. Since the zones in Q2 are low in each zone and low in the mean of their neighbors, this is because the municipalities in this quadrant have low or no cowpea productivity. In the case of Q4, they present low values in each zone and high in the mean of their neighbors, the municipalities of Boqueirão, São João do Cariri, Santo André and Alcantil are in this quadrant for presenting a high production of cowpea, standing out when compared to other municipalities, thus justifying their presence in the fourth quadrant (Q4).

The relationship between cowpea production in the Cariri Leste Paraíba microregion and the climatic covariates evaluated using regression models is shown in table 2. Based on the determination coefficient $\left(\mathrm{R}^{2}\right)$, Schwarz's Bayesian information criterion (BIC) and Akaike criterion (AIC), thus verifying that there is a model that describes the relationship between the variables involved and the criterion, which tries to maximize the probability of choosing the true model. In this sense, AIC and BIC were used as an extension of the probability optimization criterion for estimating the best predictor model (SOBER \& STEEL, 2002) according to the authors the lower the value of the indexes, the better the prediction.

According to the responses obtained in the spatial regression models (Table 1), there was a significant improvement in the results for the SEM model, which was responsible for explaining $82 \%$ of the variability of the influence of climate variables on cowpea, indicating strong correlation. With the exception of altitude, all covariables (average temperature, fallow-induced drought index and humidity index) showed an inverse association with

Table 2 - Regression models fitted to bean production data according to climatic variables in the Eastern Cariri microregion of Paraíba.

\begin{tabular}{lccc}
\hline Covariables & RC & SAM & SEM \\
\hline Intercept & 17783.8 & 20696 & 29208.1 \\
Alt & 13.3372 & 26.062 & 17.5532 \\
\hline T_Mea & -391.732 & -264.946 & -747.293 \\
\hline Irs & -1428.16 & -2226.17 & -1778.96 \\
Ih & -321.904 & -397.666 & -345.081 \\
R & 0.388041 & 0.661889 & 0.820733 \\
AIC & 183.844 & 181.019 & 168.094 \\
BIC & 186.268 & 183.928 & 170.518 \\
\hline$\rho$ & - & -0.765397 & -0.794214 \\
\hline
\end{tabular}

Alt - Altitude; T_Mea - Mean temperature; Irs - drought-induced fallow index; Humidity index.

Ciência Rural, v.51, n.12, 2021. 
production, that is, an increase in their values led to a reduction in cowpea production (in tons). These indices are directly associated with the thermohydro components of the region. Such model (SEM) presented the lowest values of AIC and BIC, 168.094 e 170.518 , respectively.

In this context (ANDRADE et al., 2006), it is highlighted that cowpea bean are sensitive to both low and high temperatures. Low temperatures prevent, retard or reduce germination and reduce branch growth and height, resulting in the production of a small number of pods per plant. In turn, high temperatures cause floral abortion, reduce pod set, pod retention, and number of seeds per pod, and favor the appearance of diseases, especially when associated with high relative humidity. Therefore, the optimum average temperature during the cycle is 18 to $24^{\circ} \mathrm{C}$ (ideal $21^{\circ} \mathrm{C}$ ).

In the analysis of the humidity index, it is important to emphasize that excess water in the soil can impair germination, limit the development of roots, favor the incidence of diseases, interfere during the flowering and fruiting stages as they are the most sensitive to poor soil aeration and, finally, during the maturation phase, prolong and delay the harvest, thus negatively affecting final productivity (ANDRADE et al., 2006).

Table 3 shows the regression models with soil covariables. The model that best fitted the data was the SEM, explaining $70 \%$ of the variability in cowpea production. The independent variables that had a positive contribution were total porosity (representing the amount of empty spaces in the soil) and texture (sand).

Soil texture must be light sandy to loamy, with a good content of organic matter, and well ventilated. The $\mathrm{pH}$, in turn, had a negative contribution, reducing the production potential.

It is important to note that the SEM with climatic components showed greater explanatory capacity in the prediction of variability of cowpea production compared to the model with pedological components. This may be associated with the nature of the spatial variability of the respective environmental variables (climatic and pedological).

In this context, CAMPOS et al. (2010) observed that the increase in air temperature may significantly affect the availability of arable land for bean crops in the state of Paraíba. Similar results were reported by SILVA et al. (2010), who stated that increased air temperatures affect the availability of favorable agricultural areas, and in particular, the productivity of cowpea in northeastern Brazil.

\section{CONCLUSION}

It was concluded that the municipalities that stood out in bean production were Boqueirão and São João do Cariri.

There was spatial autocorrelation of bean productivity with agrometeorological elements according to the statistical techniques employed, such as the Moran's index I.

Finally, the spatial regression model that best fitted the data according to the pre-established criteria was SEM, with moderate to very strong correlation intensity. This indicates that spatial dependence must be included in the models to increase the estimate of cowpea productivity in the microregion of Cariri Leste da Paraíba.

Table 3 - Regression models fitted to cowpea production data according to soil variables in the Eastern Cariri microregion of Paraíba.

\begin{tabular}{lccr}
\hline Covariates & RC & SAM & SEM \\
\hline Intercept & 3737.19 & 4376.97 & 5342.16 \\
Sand & 81.7841 & 80.0152 & 69.5572 \\
$\mathrm{pH}$ & -2098.23 & -2200.2 & -2187.62 \\
$\mathrm{Pt}$ & 139.794 & 156.884 & 134.777 \\
$\mathrm{R}^{2}$ & 0.364587 & 0.502331 & 0.705539 \\
$\mathrm{AIC}$ & 182.295 & 182.153 & 176.945 \\
$\mathrm{BIC}$ & 184.234 & 184.578 & 178.884 \\
$\rho$ & - & -0.464948 & -0.948132 \\
\hline
\end{tabular}

Pt - Total porosity. 


\section{ACKNOWLEDGEMENTS}

The authors would like to thank the Unidade Acadêmica de Ciências Atmosféricas of the Universidade Federal de Campina Grande (UFCG) for the structure provided and also the Coordenação de Aperfeiçoamento de Pessoal de Nivel Superior (CAPES), for the scholarship granted to the first author and Conselho Nacional de Desenvolvimento Científico e Tecnológico (CNPq) for financing Research Projects under number 409499/2018-8.

\section{DECLARATION OF CONFLICT OF INTEREST}

The authors declare no conflict of interest. The founding sponsors had no role in the design of the study; in the collection, analyses, or interpretation of data; in the writing of the manuscript, and in the decision to publish the results.

\section{AUTHORS' CONTRIBUTIONS}

All authors contributed equally for the conception and writing of the manuscript. All authors critically revised the manuscript and approved of the final version.

\section{REFERENCES}

ALMEIDA, E. S. et al. There is spatial convergence of agricultural productivity in Brazil. Revista Economia e Sociologia Rural, v.46, n.1, p.31-52, 2008. Available from: $<$ https://doi.org/10.1590/ S0103-20032008000100002>. Accessed: Feb. 10, 2020. doi: 10.1590/S0103-20032008000100002.

ALVES, F. A. L. et al. Chemical and nutritional variability of cactus pear cladodes, genera Opuntia and Nopalea. American Journal of Food Technology, v.12, n.01, p.25-34, 2017. Available from: $<$ https://scialert.net/abstract/?doi=ajft.2017.25.34>. Accessed: Feb. 10, 2020. doi: 10.3923/ajft.2017.25.34.

ANDRADE,M.J.B. et al. Exigências edafoclimáticas. In: VIEIRA, C.; PAULA JÚNIOR, T.J.; BORÉM, A. (Eds.). Feijão. 2. ed. Atual. Viçosa: Ed. UFV, 2006. p.67-86.

BEDDINGTON, J. et al. Achieving food security in the face of climate change: Final LCGIAR Research Program on Climate Change, Agriculture and Food Security (CCAFS). Copenhagen, Denmark, 2012.

BIVAND, R S. et al.,.Comparing Implementations of Estimation Methods for Spatial Econometrics. Journal of Statistical Software, v.63, n.18, p.1-36, 2015. Available from: <https:// www.jstatsoft.org/article/view/v063i18>. Accessed: Feb. 10, 2020. doi: 10.18637 / jss.v063.i18 .

CÂMARA, G.; MONTEIRO, A. M. V. Conceitos básicos em ciência da geoinformação. São José dos Campos: INPE, 2004, $346 \mathrm{p}$.

CÂMARA, G. et al. Análise espacial e geoprocessamento. In: Druck, S.; Carvalho, M.S.; Câmara, G.; Monteiro, A.V.M. (eds). Análise Espacial de Dados Geográficos, Brasília, EMBRAPA, 2004
CAMPOS, J. H. B. C. et al. Impacto do aquecimento global no cultivo do feijão-caupi, no Estado da Paraíba. Revista Brasileira de Engenharia Agrícola e Ambiental, v.14, n.4, p.396-404, 2010.Available from: <https://doi.org/10.1590/S141543662010000400008> Accessed: Dec. 10, 2019. doi: 10.1590/ S1415-43662010000400008.

CORRAR, L. J.; PAUlO, E.; DIAS FILHO, J. M. Análise multivariada para cursos de Administração, Ciências Contábeis e Economia. São Paulo: Atlas, 2007.

CUNHA, A. R.; MARTINS, D. Classificação climática para os municípios de Botucatu e São Manuel, SP. Irriga, v.14, n1, p.1-11, 2009. Available from: <https://doi.org/10.15809/ irriga.2009v14n1p1-11>. Accessed: Dec. 10, 2019. doi: 10.15809/ irriga.2009v14n1p1-11.

DOBSON, A J.; BARNETT, A. G. An introduction to generalized linear models." StatisticalPapers, v.53, n.3, p. 805-806, 2011.

INSTITUTO BRASILEIRO DE GEOGRAFIA E ESTATÍSTICA CONTAGEM DA POPULAÇ̃̃O (IBGE) 2010. Available from: <http://cidades.ibge.gov.br/xtras/perfil. php?lang=\&codmun=250053 $>$. Accessed: Jan. 24, 2020.

INSTITUTO BRASILEIRO DE GEOGRAFIA E ESTATÍSTICA (IBGE) 2015. Cidades: Paraíba: informações estatísticas. In CensoDemográfico 2015. Available from: < http://www.ibge.gov. br>. Accessed: Jan. 29, 2020.

INSTITUTO NACIONAL DO SEMIÁRIDO (INSA). O Semiárido brasileiro: riquezas, diversidade e saberes. 2014. Available from: <https://portal.insa.gov.br/acervo-cartilhas/699o-semiarido-brasileiro-riquezas-diversidades-e-saberes $>$. Accessed: Jan. 21, 2020.

LESAGE J.P., FISCHER M.M. Spatial Econometric Methods for Modeling Origin-Destination Flows. In: Fischer M., Getis A. (eds) Handbook of Applied Spatial Analysis. Springer, Berlin, Heidelberg, 2010.

LITER, G.; BURSZTYN, M. Family farmers' perceptions and Adaptation Strategies to Climatic and Socioeconomic Risks in the Pampa Biome-South America. Ambiente e Sociedade, v.18, n.3, p.55-80, 2015. Available from: <http://dx.doi.org/10.1590/18094422ASOC668V1832015>. Accessed: Jan. 10, 2020. doi: 10.1590/1809-4422ASOC668V1832015.

NASCIMENTO, S.S.; ALVES, J.J.A. ECOCLIMATOLOGY OF THE CARIRI PARAIBANO.Revista Geográfica Acadêmica, v.2, n.3, p.28-41, 2008.

NASUTI, S. et al. Os desafios da agricultura no Semiárido brasileiro. Sustentabilidade em debate v.4, n.2, p.276-298, 2013. Available from: <https://doi.org/10.18472/SustDeb.v4n2.2013.10049>. Accessed: Jan. 10, 2020. doi: 10.18472/SustDeb.v4n2.2013.10049.

ROWNTREE, D.; O'HEHIR, R. Statistics without tears: A primer for non-mathematicians. Penguin Har-mondsworth, 1981.

SENA, J.P.O. et al. Comparison between rainfall data obtained from the Climate Prediction Center and actually measured in the Cariri region of Paraiba state, Brazil. Revista Brasileira de Geografia Física, v.5, n.2, p.412-420, 2012. Available from: $<$ https://doi.org/10.26848/rbgf.v5.2.p412-420>. Accessed: Jan. 10, 2020. doi: $10.26848 /$ rbgf.v5.2.p412-420. 
SILVA, V. P. R. et al. Yield forecasting model for rainfed crops in the semi-arid region of Northeast Brazil. Revista Brasileira de Engenharia Agrícola e Ambiental, v.6, n.1, p.83-87, 2002. Available from: <https://doi.org/10.1590/S141543662002000100015>. Accessed: Jan. 10, 2020. doi: 10.1590 S1415-43662002000100015.

SILVA, V. de P. R. et al. Impact of global warming on cowpea bean cultivation in northeastern Brazil. Agricultural Water Management, v.97, n.11, p.1760-1768, 2010. Available from: $<$ https://doi.org/10.1016/j.agwat.2010.06.006>. Accessed: Jan. 10, 2020. doi: 10.1016/j.agwat.2010.06.006.

SILVA, M. T. et al.Estudo da relação entre monitoramento climático e a produção agrícola de grãos nos estados da Paraíba, Rio Grande do Norte e Ceará. Revista Brasileira de Geografia Física, v.4, n.2, p.433-447, 2011a. Available from: <https://doi. org/10.26848/rbgf.v4.2.p322-335>. Accessed: Jan. 10, 2020. doi 10.26848/rbgf.v4.2.p322-335.

SILVA, M. T. et al. Variabilidade da área de cultivo do algodão herbáceo em sistema de sequeiro no nordeste do Brasil segundo cenários de mudanças climáticas. Revista Brasileira de Geografia Física, v.4, n.3, p.448-464, 2011b. Available from: <https://doi. org/10.26848/rbgf.v4.3.p413-428>. Accessed: Jan. 10, 2020. doi: 10.26848/rbgf.v4.3.p413-428.

SILVA, M.T. et al.O cultivo do algodão herbáceo no sistema de sequeiro no Nordeste do Brasil, no cenário de mudanças climática. Revista Brasileira de Engenharia Agrícola e Ambiental, v.16, n.1, p.80-91, 2012.Available from: <http://dx.doi.org/10.1590/S1415-43662012000100011>. Accessed: Jan. 10, 2020. doi: 10.1590/S1415-43662012000100011.

SOBER, E.; STEEL. M. Testing the hypothesis of common ancestry. J. Theoret. Biol., v.218, p.395-408, 2002.

THORNTHWAITE, C. W. An approach towards a rational classification of climate. Geographical Review, London, v.38, p.55 - 94, 1948 .

VERMEULEN, S. J. et al. Agriculture, Food Security and Climate Change: Outlook for Knowledge, Tools and Action. CCAFS Report 3. CGIAR-ESSP Program on Climate Change, Agriculture and Food Security, 2010 p.1-16. 